$551.573: 551.576 .11$

\title{
On Some Coastal Clouds over Ishikari Bay, Hokkaido ${ }^{1)}$
}

\author{
By Katsuhiro Kikuchi \\ Faculty of Science, Hokkaido University, Sapporo \\ (Manuscript received 1 August 1964)
}

\begin{abstract}
In winter, early in the morning, there was sometimes observed a low cloud layer near the coast of Ishikari Bay, Hokkaido. Still and motion pictures of this type of cloud layer were taken from the top of Mt. Teine. The results indicate that these clouds seem to have been caused by the mixing of relatively warm air over the bay and cold air flowing out from the Ishikari Plain. These "coastal clouds" occurred only on a clear morning which follows a clear night, and they were found only over the coast of the bay. The observed clouds were small in scale, and it did not produce precipitation. It is expected, however, that such clouds may occur on a larger scale in other places, and that it may produce precipitation even if there is no front nor mountain.
\end{abstract}

\section{Introduction}

During a series of observations of snowfall conducted at some places in the Ishikari Plain (Magono and Kikuchi, 1964), a very low cloud layer was occasionally observed over Ishikari Bay. The characteristics of these clouds were that it appeared only on a clear morning which followed a clear night, and that the clouds became cellular as the sun rose, and finally disappeared. So far as the clouds the author observed were concerned, snow did not fall from them. Nevertheless, since these clouds seemed to be very peculiar and unusual, he determined to carry out observation from 1963 through 1964. The objective of this paper is to present photographic as well as meteorological analysis obtained in this project.

\section{Photographic observations}

In the winter of 1963, the clouds were photographed from the top of Mt. Teine (1024 m high) with a $24 \times 36 \mathrm{~mm}$ camera with a lens of $35 \mathrm{~mm}$ focal length. In 1964, a $16 \mathrm{~mm}$ movie camera was also used. The $35 \mathrm{~mm}$ camera was panned clockwise about $180^{\circ}$ from NW to SE so as to include both the clouds and the surrounding geographical

1) This work was supported by the U.S. National Science Foundation under Contract G-18830. features. The latter was very useful in determining the height and horizontal distribution of the clouds. The observation area is shown in Fig. 1. The pictures were

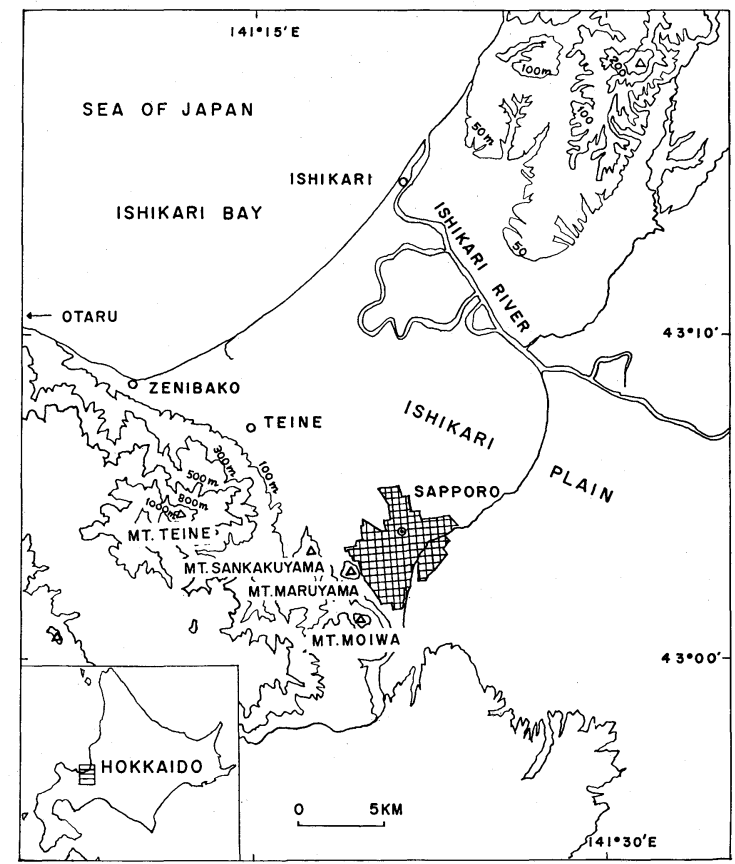

Fig. 1. Topographical map of observation area.

taken every ten minutes from early morning until the time when the clouds dissipated. A $16 \mathrm{~mm}$ time lapse movie camera was also

Vol. 42, No. 6, 1964 
used to take the time evolution of the clouds.

\section{Photographic analyses}

Photo. 1 shows one of the typical examples of these clouds formed along the coast. Photos. 2 and 3 are panoramic photographs taken on 26 January 1963 and 31 January 1964, respectively, showing the time changes of cloud appearances. The surrounding geographical features are shown in the diagram in Photo. 2. Since these observations were made from a single point, it was necessary to assume a cloud height in order to determine the horizontal distribution. It is assumed that the height of the clouds was the same as that of the smog layer covering Sapporo city. It is quite often the case that smog extends from Sapporo to northwest, and it connects with the low level clouds located there. The height of the smog in this case was estimated by comparison with the heights of the Mountains, Moiwa (531 m), Sankakuyama (312 m) and Maruyama (226 $\mathrm{m}$ ) near the south-western edge of Sapporo. The horizontal distribution of the clouds was analyzed with the aid of the value of smog heights obtained above and the horizontal direction determined from the photographs. The horizontal distribution of the clouds in Photos. 2 and 3 are shown in Figs. 2 and 3. Since it is impossible to take pictures of the clouds before the sunrise, the origin and the feature of the early stage of cloud development could not be investigated. It is, however, certain that the clouds only occurred near the coast of Ishikari Bay. As may be judged from Photos. 2 and 3, the top of the clouds began to ascend after the sunrise, then the clouds became cellular, and it finally dissipated at about 10:00 JST. Two examples of 26 January, 1963, and 31 January, 1964, will be explained in the followings.

26 January, 1963 Photo. 2 shows the changes in cloud form and distribution at one hour interval. The analyzed result from these photographs is presented in Fig. 2. The observation started at $08: 02$. At this

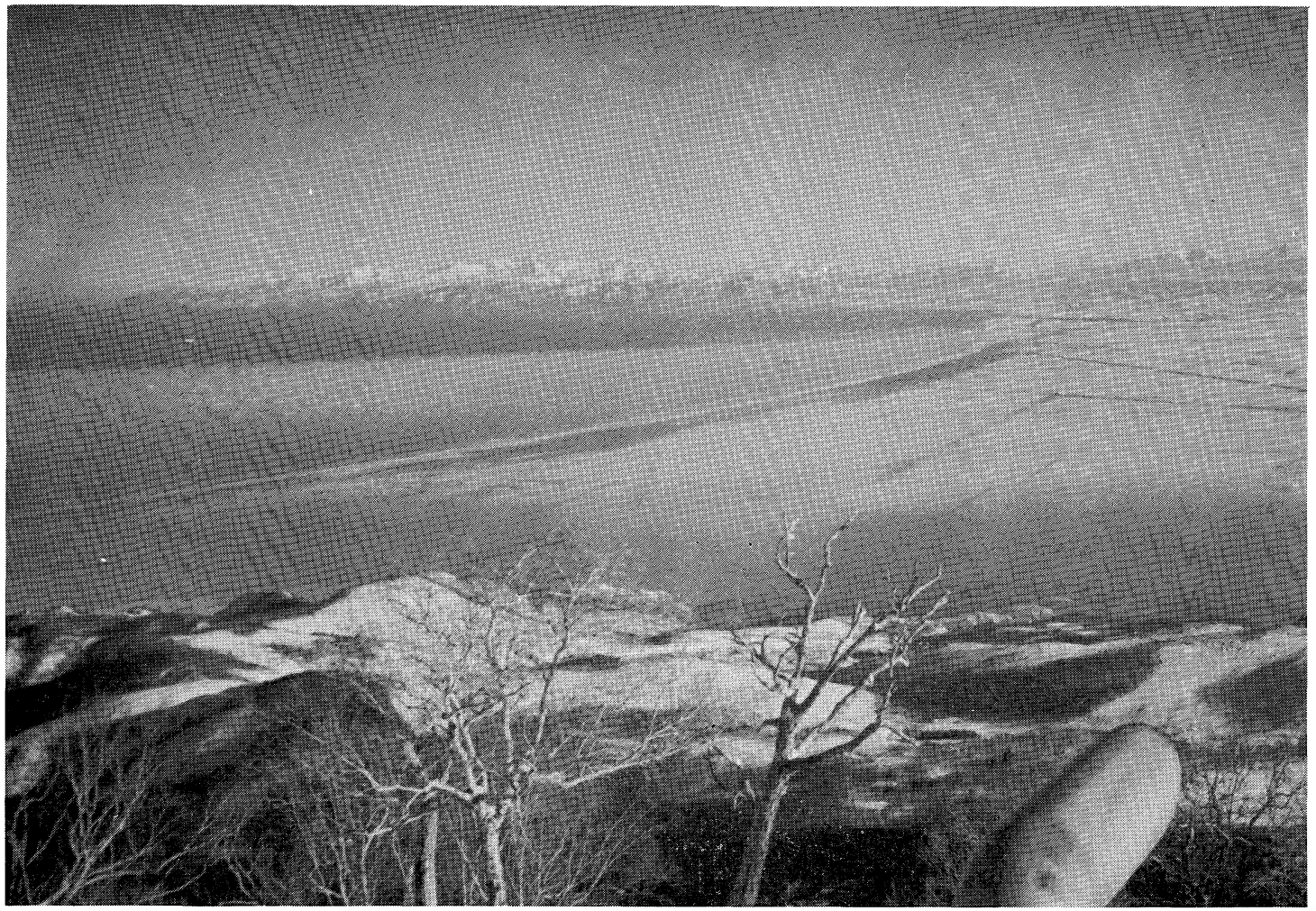

Photo. 1 Typical coastal cloud, 26 January 1963.

Journ. Met. Soc. Japar 

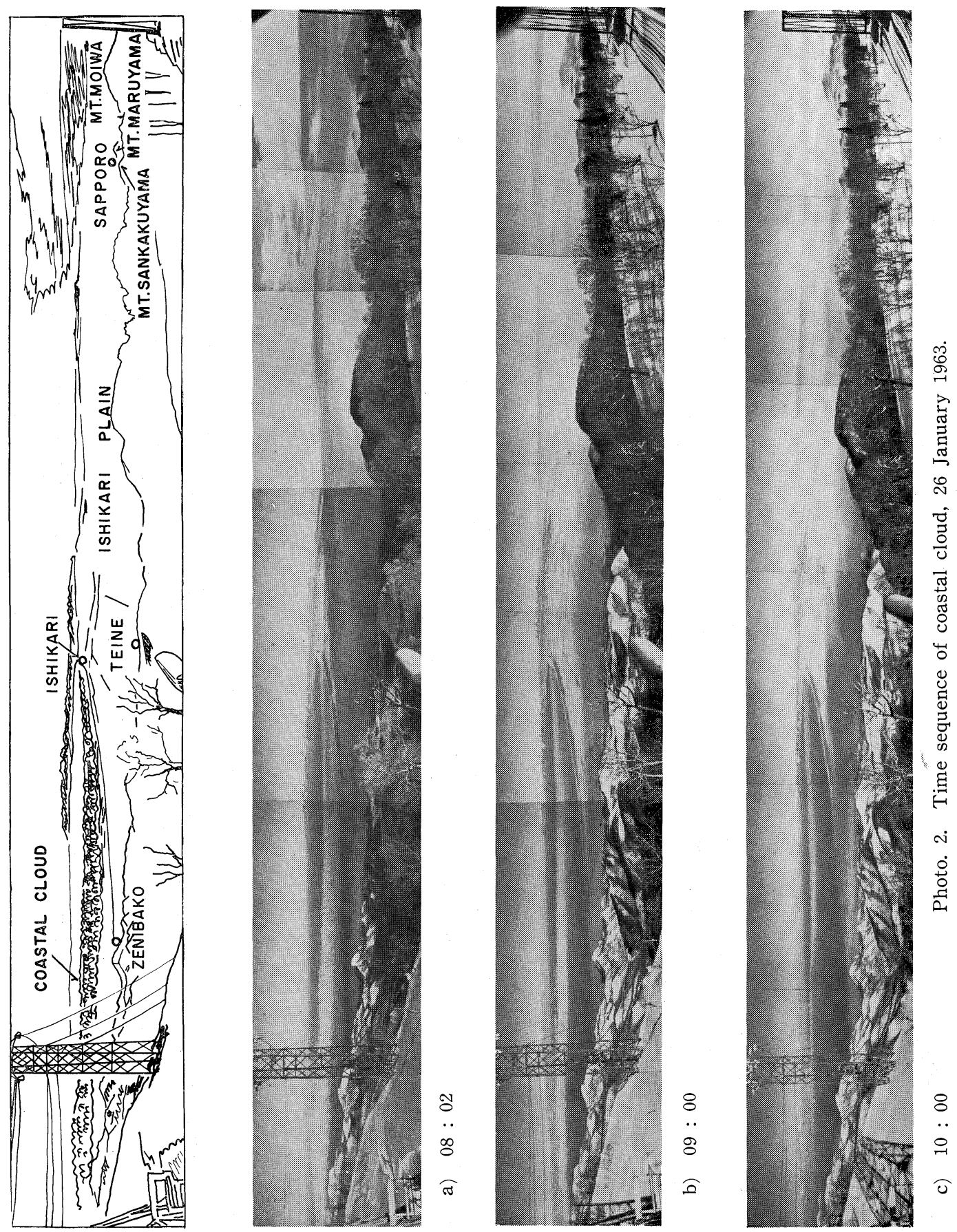

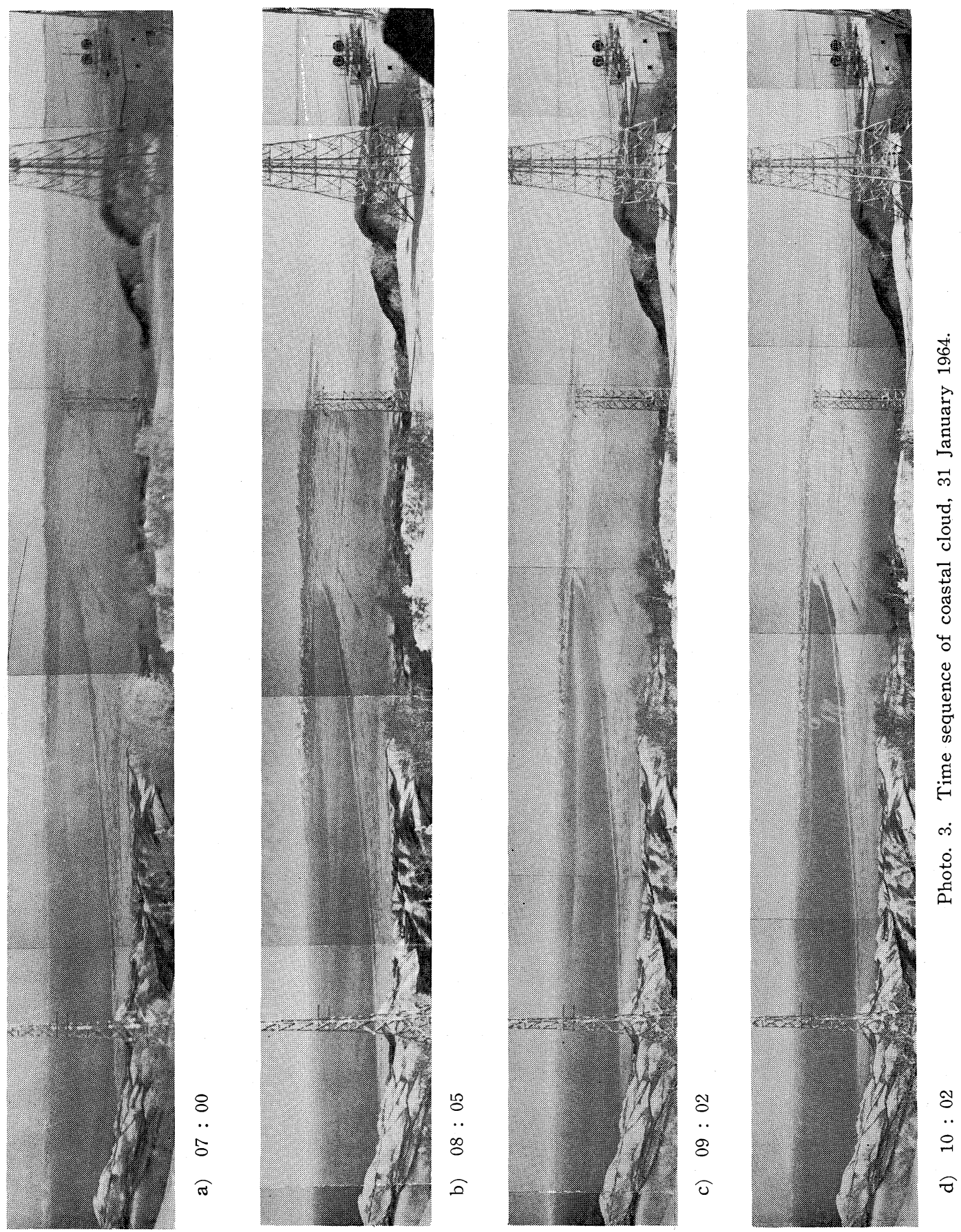

Journ. Met. Soc. Japan 
time, the clouds were already well developed ; the front at the northern edge of the cloud extended to the northwest off Otaru harbor. The cloud was composed of many small cells and it existed only over the bay and west of the mouth of the Ishikari River. The extension of the cloud was approximately $13 \mathrm{~km}$ in width. Furthermore, the cloud was evenly distributed in many lines parallel to the direction of the extension. The height of the cloud top was less than $200 \mathrm{~m}$. At $09: 00$, the front of the cloud extended farther to the northwest, while its height was kept to be approximately $200 \mathrm{~m}$. It then became gradually thinner in the northwestern part. At 10:00 it appeared to be extremely thin, and the majority of the cloud was located over the middle of the bay. The height of the cloud was increased to approximately $250 \mathrm{~m}$. At $10: 40$, almost all of the cellular cloud had dissipated, and only a few scattered patches remained.

31 January, 1964 In 1964, observation started earlier in the morning to investigate the initial development of the cloud layer. As may be seen in Photo. 3 and Fig. 3, at
$07: 00$, the layer was distributed all over the coast line of Ishikari Bay at a height of only approximately $50 \mathrm{~m}$. This layered cloud was distinctly different in form from the cloud observed the year before. At $08: 16$, the layered cloud had changed to a fibrous type with each line consisting of convective cellular clouds. The cloud became to resemble that observed in the previous year except a portion near the coast. The front of the cloud dissipated gradually. It is felt that the behavior of the cloud at this time corresponded to that of the cloud observed at $08: 02$ on 26 January, 1963 . At $09: 02$, the cloud began to fade rapidly and dissipated from the coast. This is the same pattern as was observed at 10:00 in the 1963's case, but the top of the cloud was only approximately $100 \mathrm{~m}$ high, about one half of that in the previous year. At $09: 35$ the height of the cloud top was increased to approximately $150 \mathrm{~m}$, and the form of the cloud entirely differed from the appearence in its early stage. At $10: 02$, there remained a small area of cloud around the mouth of the Ishikari River.

In January, 1963, such low level coastal

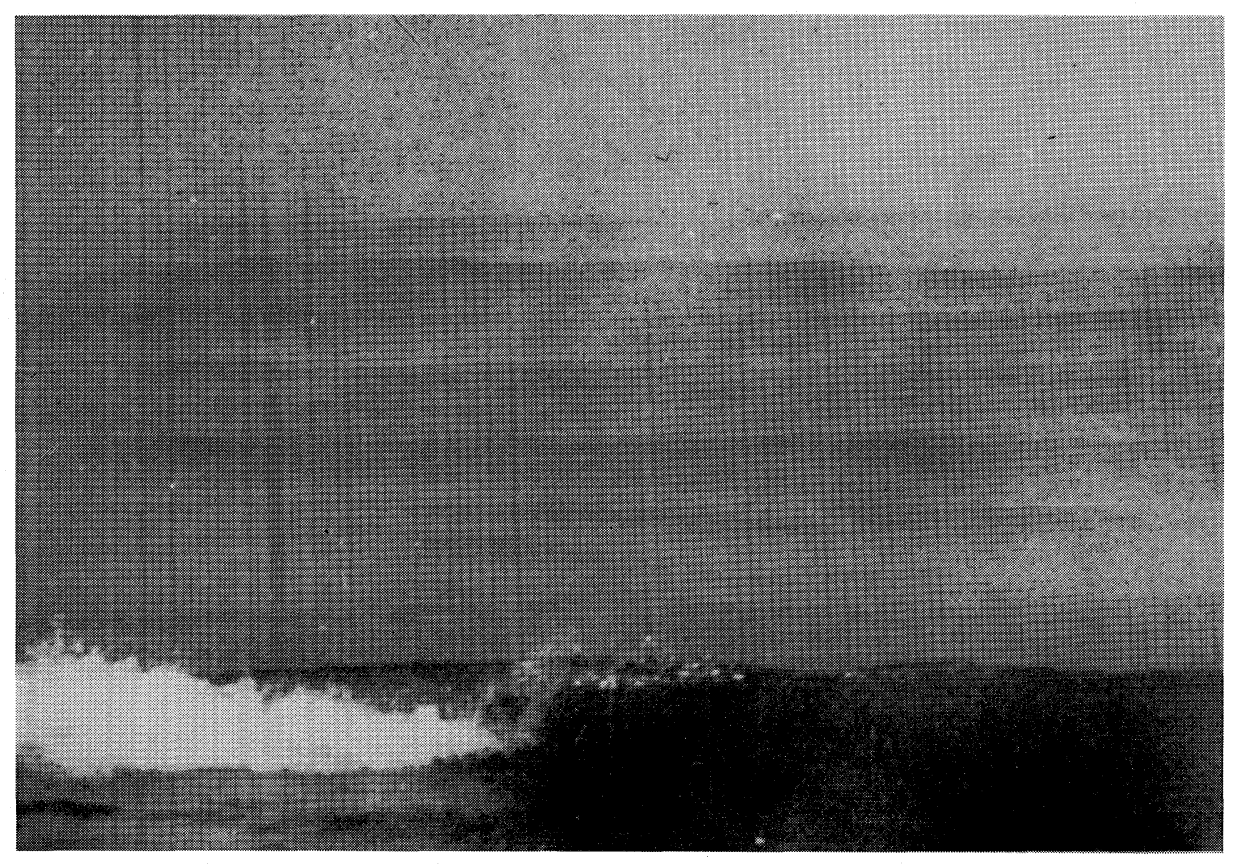

Photo. 4. Coastal cloud (vigorous steaming from the sea surface) on Ishikari Bay, taken from the shore of the bay. 
clouds were observed four times. During this year the observations were begun at about 08:00 and the cloud layer already consisted of convective cellular clouds evenly distributed in many lines running from southeast to northwest. While in 1964 similar clouds were observed in five occasions. All of them were thin when first observed at $06: 30$, which later changed to cells distributed in many lines running from southeast to northwest, i.e., the direction of the prevailing wind as will be described below.

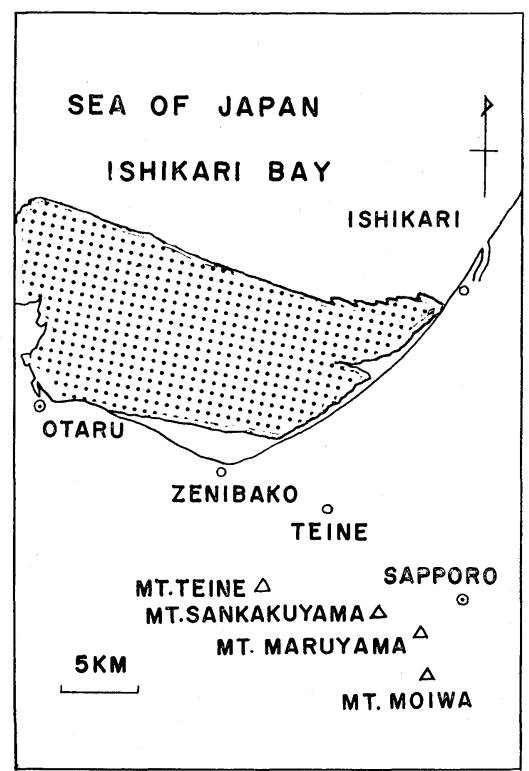

a) $08: 02$

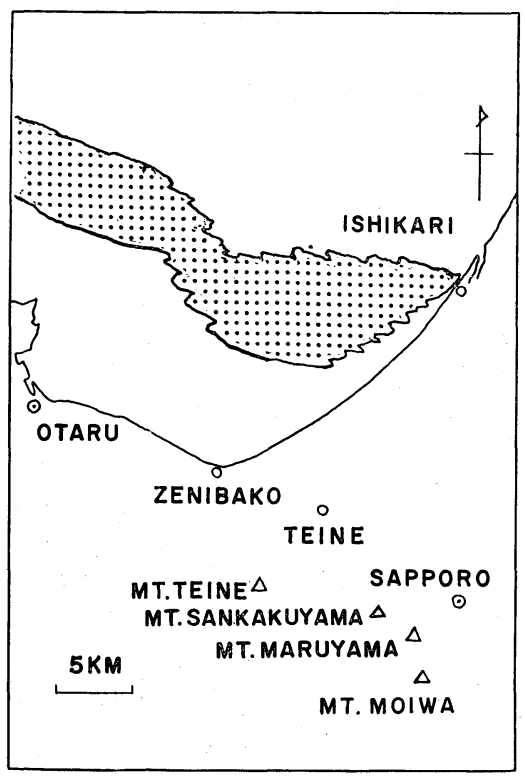

c) $10: 00$

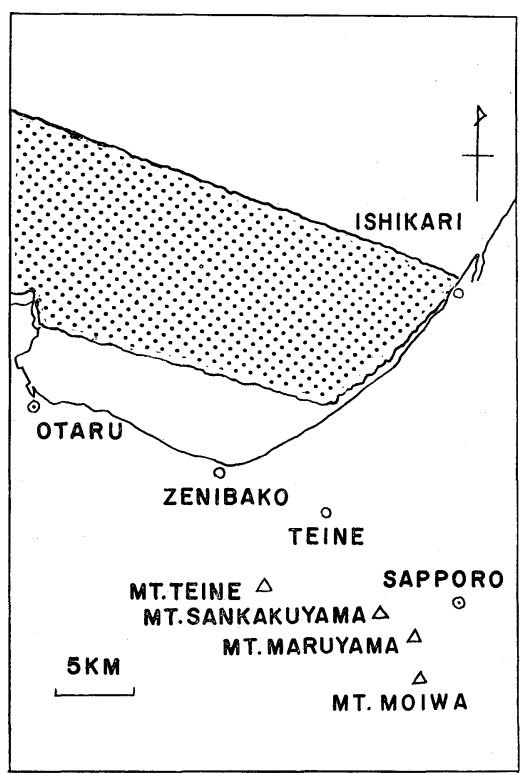

b) $09: 00$

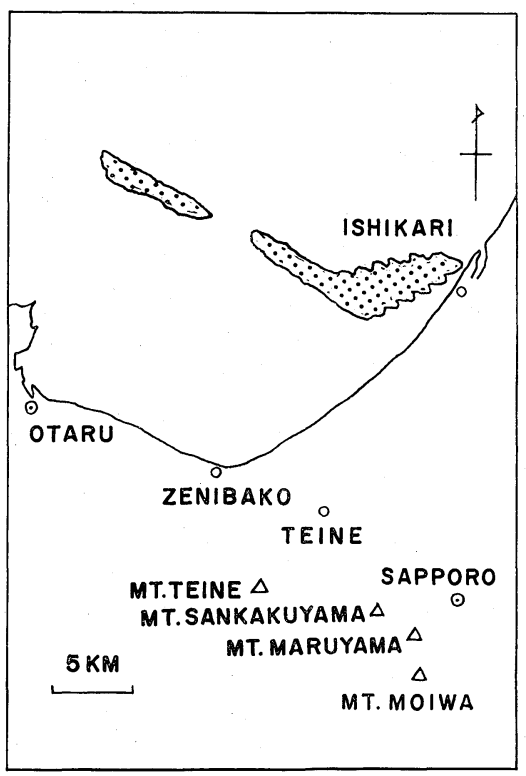

d) $10: 40$

Fig. 2. Time sequence of horizontal distribution of coastal clouds, 26 January 1963. 


\section{Meteorological analyses}

4.1) Surface wind direction and velocity

Since it was noticed in 1963 observations that the direction of the clouds seemed to agree with that of the prevailing wind, the

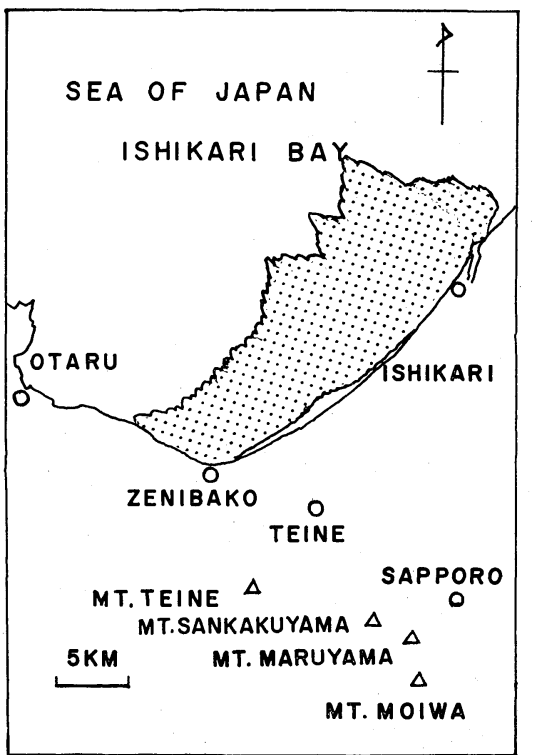

a) $07: 00$

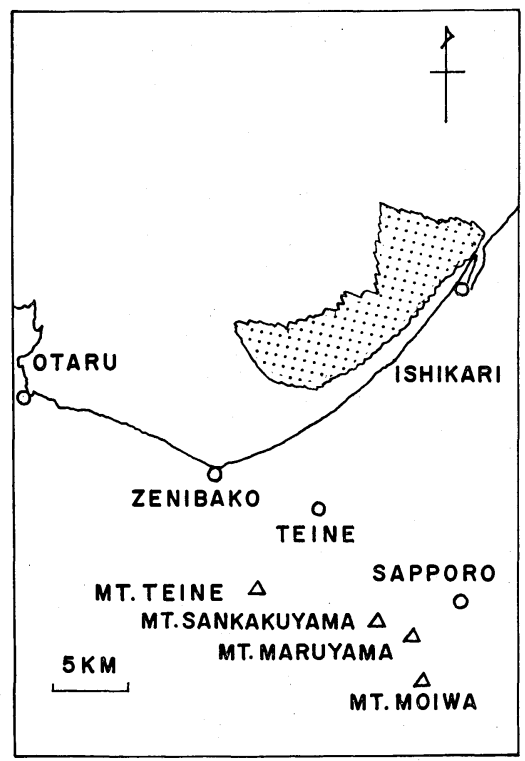

c) $09: 02$ author first used data from three weather stations near Ishikari Bay to determine the hourly surface wind direction and velocity. The three stations are Sapporo District Meteorological Observatory, Otaru Weather Station, and Ishikari Branch of Ishikari River

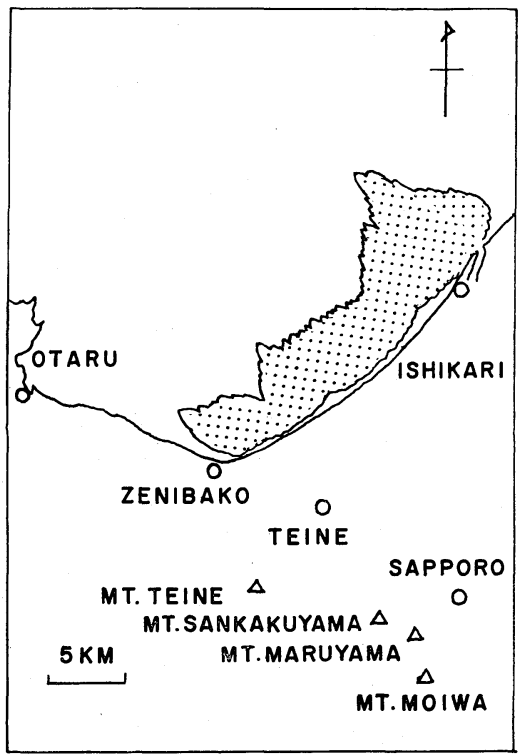

b) $08: 05$

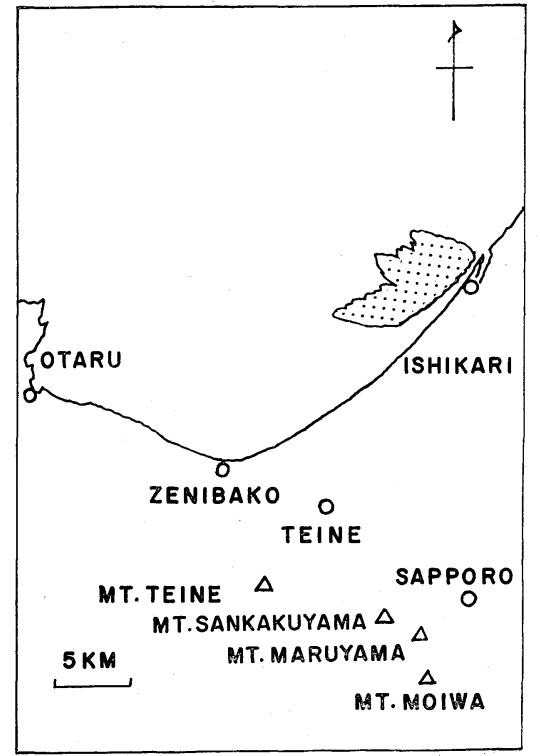

d) $10: 02$

Fig. 3. Time sequence of horizontal distribution of coastal clouds, 31 January 1964. 
Control Office belonging to the Hokkaido Development Bureau. All of the data from these three stations indicated that the prevailing wind was southerly, especially at Ishikari. This local wind direction was opposite to that expected from the general synoptic surface pressure pattern in winter. In the following year the author made wind and temperature analysis using the data from approximately 60 railway stations on the Ishikari Plain. The results for the observation time, 08:00 are shown in Figs. $4 \mathrm{a}$ and b. Fig. 4a shows the horizontal wind and temperature distributions for 31 January, 1964, and Fig. $4 \mathrm{~b}$ for 10 February, 1964. Typical coastal clouds were formed. The left diagrams in the figures are the streamlines based upon the observed surface wind at 08:00, and the right the isotherms. As is illustrated by the streamlines, the wind was southerly at the coast of Ishikari Bay, northerly in inland as well as at the coast of the Pacific Ocean. The patterns of the streamlines on both dates as well as those of the isotherms are similar to each other. It is remarkable that there was an extremely cold area in the northern part of the plain about $40 \mathrm{~km}$ apart from Sapporo. Judging from the streamlines and the isotherms, the wind was blowing out from this cold area. It was therefore considered that the southerly wind along the coast of Ishikari Bay resulted from this wind system together with the effect of the mountain range to the west of the plain. The cold area was presumably produced by strong radiational cooling in the previous clear night.

\section{2) Vertical distribution of the wind direc- tion}

According to the analyses mentioned in the previous section, the prevailing wind was southerly at the observation points along the coast of Ishikari Bay. In order to make the discussions more complete, we have to study the variation of the wind in the verti cal. For this purpose, the vertical distribution of the wind direction up to a height of $3 \mathrm{~km}$ at Sapporo was examined. Two examples of these analyses are given in Fig. 5 ; one is for five days from 23 through 28 January and the other for 21 February, 1963, the observation time being $09: 00$ and $21: 00$.
Note that these days correspond to those just before and after the coastal clouds were observed. In these figures the mark "clouds" indicates the height of the observed clouds. In all the cases, there was little difference in the wind direction above $1 \mathrm{~km}$ level between the observations at $09: 00$ and $21: 00$ in the previous night. At levels lower than $1 \mathrm{~km}$, however, a difference may be recognized especially when the coastal cloud was observed. Wind direction in the lower levels changed discontinuously between night and early morning.

4. 3) Vertical distribution of the wind velocity

The vertical distribution of wind velocity up to a height of $3 \mathrm{~km}$ over Sapporo were analyzed for the same dates and times. and the results are shown in Fig. 6. At altitudes below $1 \mathrm{~km}$, winds were always very light, say, less than $5 \mathrm{~m} / \mathrm{sec}$ when the clouds appeared. No clouds were observed when wind velocity was greater than $10 \mathrm{~m} / \mathrm{sec}$. It may be concluded from this fact that the calm air is necessary to produce the coastal cloud. This may be related to the strong surface inversion which will be described later.

\section{4) Vertical distribution of the air tempera- ture}

The surface inversio was investigated (Fig. 7) and the temperature gradient below the inversion was computed when it existed. The temperature gradie ts, defined here by the mean value of temperătture gradient below the inversion, ranged from 1.5 to $3.0^{\circ} \mathrm{C} /$ $100 \mathrm{~m}$, while no temperature inversion nor temperature gradient more than $0.5^{\circ} \mathrm{C} / 100 \mathrm{~m}$ was observed on normal days. These analyses were based on the soundings at Sapporo. It is probable that the temperature gradients beneath the inversion over the cold area of the northern Ishikari Plain could be much greater.

\section{5) Sea surface temperature}

On the Ishikari Plain, the air temperature appears sometimes to be below $-20^{\circ} \mathrm{C}$ on fine mornings following a still, clear winter night. It is noted that there is no fast ice nor drift ice in Ishikari Bay and that the sea water is fairly warm. Observations by Hokkaido Regional Fisheries Research Laboratory (1952) and the 1st Regional Maritime Safety Headquarters (1954) reported that the mean sur- 

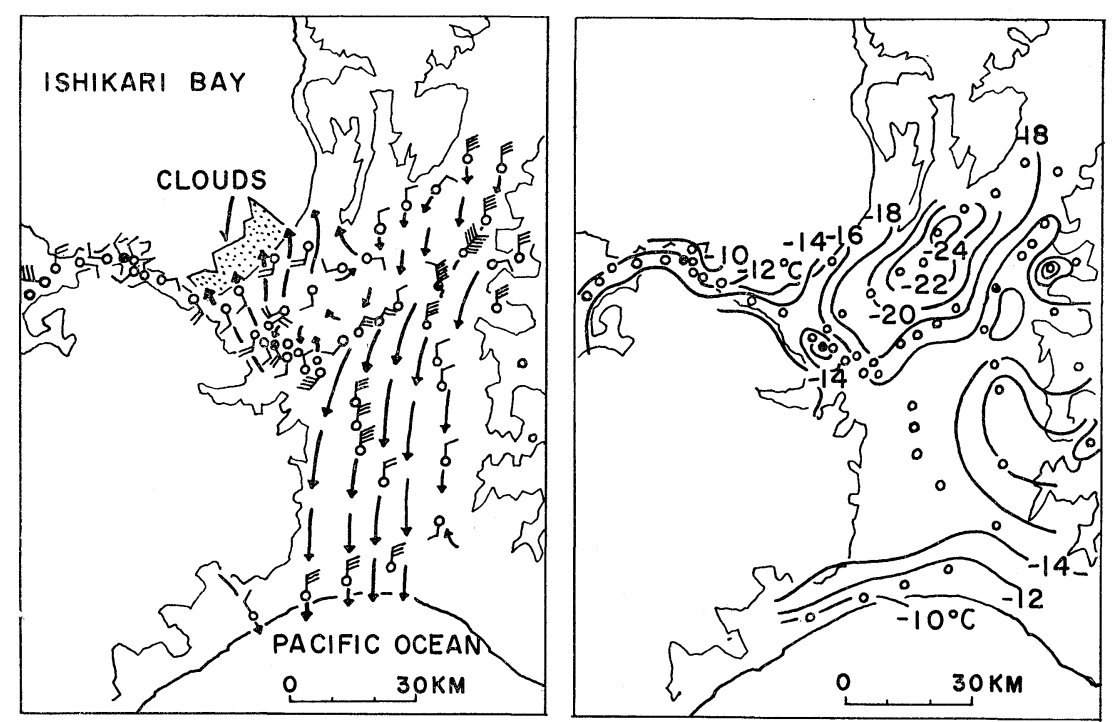

a) $08: 00 \quad 31$ January 1964
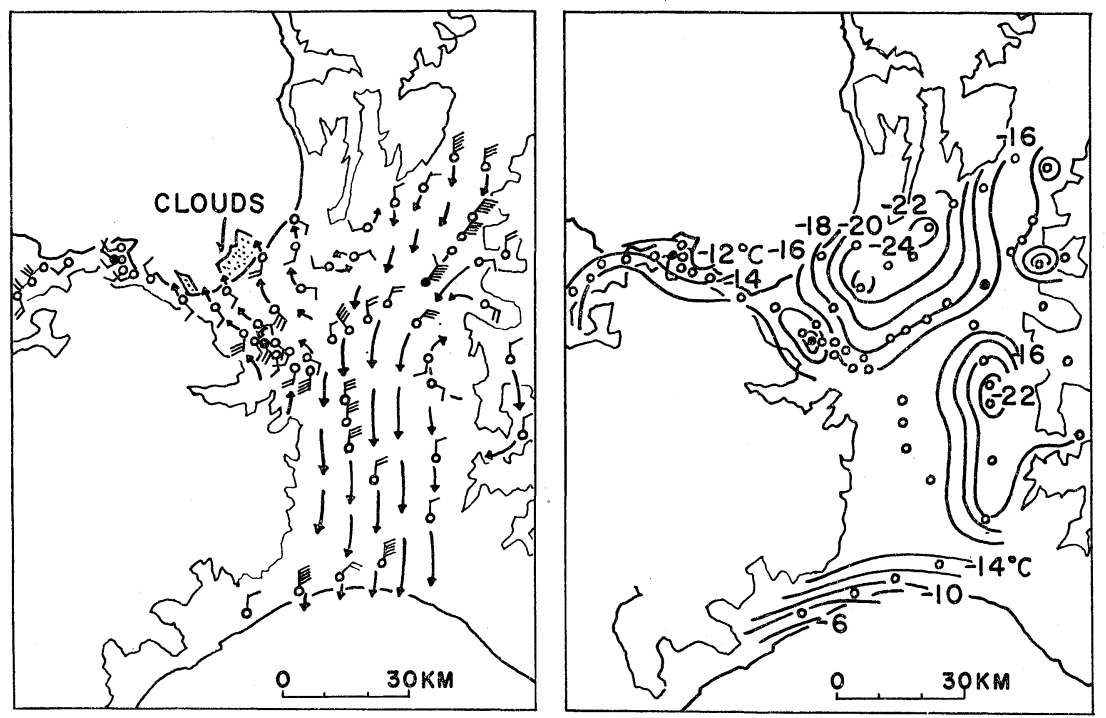

b) $08: 00 \quad 10$ Feburary 1964

Fig. 4. Surface winds and isotherms.

face temperature of the sea in January and February is about $+4 \sim+6^{\circ} \mathrm{C}$, varying from year to year. The measured sea surface temperature near the coast in early February 1964, was about $+5^{\circ} \mathrm{C}$. Therefore, the temperature difference between the surface of the water in Ishikari Bay and the cold area on the Ishikari Plain could be greater than $25^{\circ} \mathrm{C}$ on some occasions. It is clear that this large temperature difference induces the outflow of the cold air over the plain into the bay.

4. 6) Surface pressure difference

The difference in surface pressure between Sapporo (in the middle of the plain) and Otaru (near the sea) for the time of occurrence of the coastal clouds may provide us with an irnportant information on the mechanism of the clouds. The surface pressures in $\mathrm{mb}$ at Sapporo and Otaru for the $22 \mathrm{nd} \sim 28$ th of January, 1963 (09:00 09:00) are shown in Fig. 8. The pressure difference in $\mathrm{mb}$ 


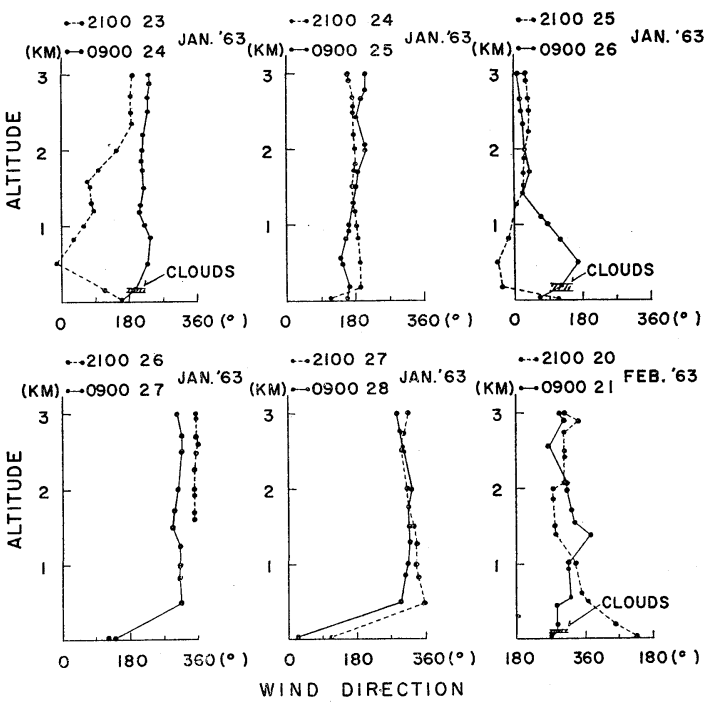

Fig. 5. Vertical distribution of wind direction at Sapporo.

between the two cities is given at the bottom of the figure. Black circles show the values at Sapporo and white circles, at Otaru. The pressures were plotted at three hour intervals. Although the two curves show similar changes with time, the surface pressure at Sapporo was always slightly higher than at Otaru. Because the general synoptic pressure pattern in the winter of Japan is usually of the type of the "west high, east low" as shown in Fig. 9a, it is generally assumed that the pressures are higher at Otaru which is located to the west of Sapporo. However, the actual pressure difference during this period was opposite to this general tendency. This suggests that these were formed a meso-high over the plain due to radiational cooling, and a meso-low over the bay (Fig. $9 \mathrm{~b})$. The example observed on 26 January, 1963 was especially pronounced. The pressure difference in the early morning was $2 \mathrm{mb}$, but by noon the pressures at the two stations turned out to be approximately the same. This is a typical example which shows the disappearance of the pressure difference when the coastal cloud was dissipated.

\section{Discussion}

According to the foregoing analyses, it is considered that these coastal clouds were produced by interaction between the cold air streaming out from the Ishikari Plain and

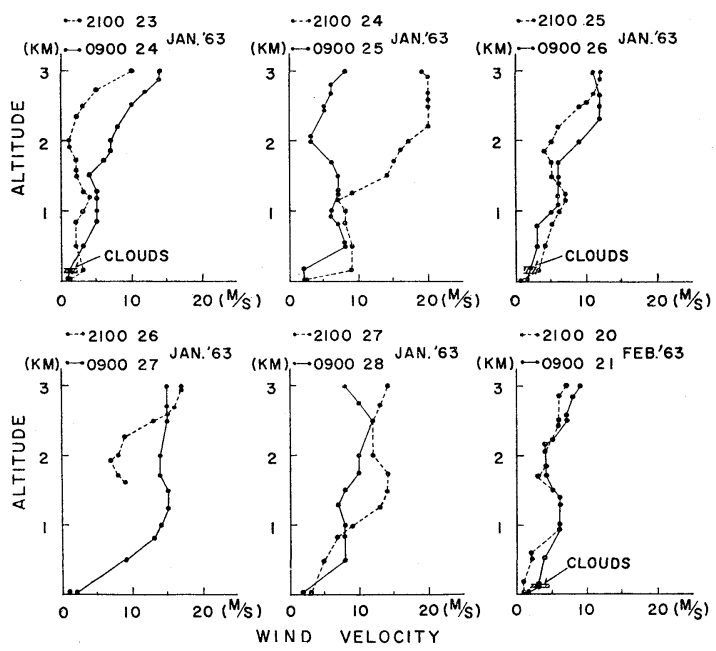

Fig. 6. Vertical distribution of wind velocity at Sapporo.

the warm sea water in Ishikari Bay. This consideration is also supported by the fact that the distribution of the coastal clouds was limited to the bay and bounded by the shoreline as is shown, for example, in Fig. 10. In this figure the postulated mechanism of development of the clouds is shown schematically. In the upper diagram showing a vertical section, the cold air (black arrows) first flows out from the cold area on the plain into the bay, and the cold air covers the sea surface. Then it undergoes vertical mixing with the warm air aloft (white arrows). Thus the "coastal clouds" are formed. The condition on the sea surface may be imagined from Photo. 4 which was taken from the shore at Ishikari: it is seen that the white steam is comming up vigorously from the sea surface. This shows that a strong vertical mixing is taking place near the sea surface. The top of the moist air (dotted region) in the upper figure of Fig. 10 would be suppressed by a low level inversion (less than $50 \mathrm{~m}$ ). A typical horizontal distribution of the clouds is shown in the lower portion of Fig. 10. It should be noted that the right side boundary of the cloud region coincides with the position of the mouth of the Ishikari River, from which cold water pours out northward and flows away along the coast as shown by the thin arrows. After the sunrise, the cold air region 

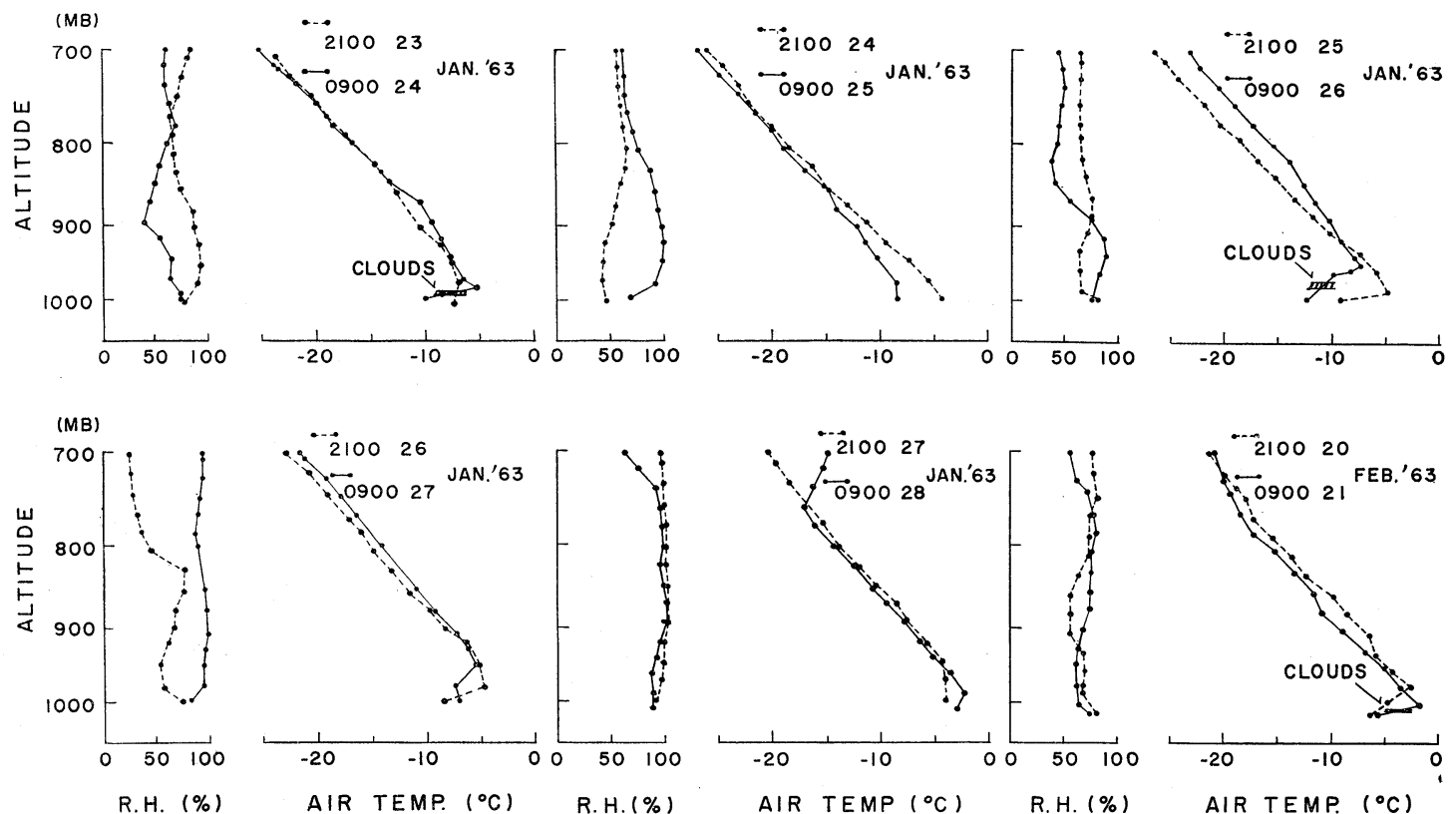

Fig. 7. Vertical distribution of air temperature and relative humidity at Sapporo.

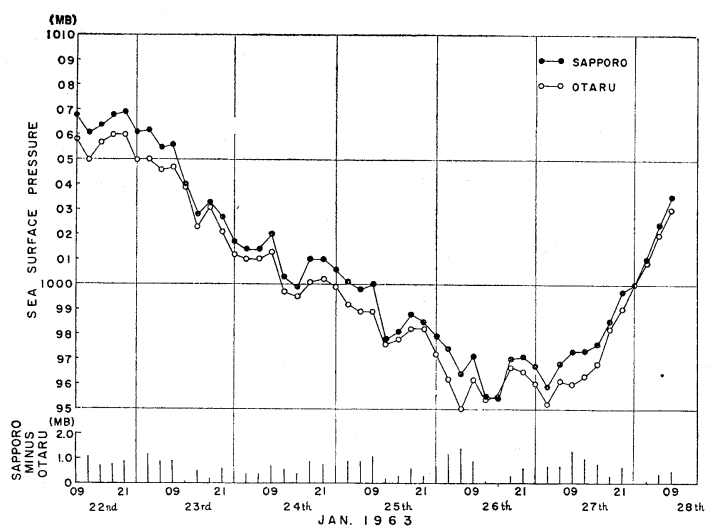

Fig. 8. Surface pressures at Sapporo and Otaru.

inland is dissipated by solar radiation and the supply of the cold air diminishes. On the other hand, the top of the inversion layer rises (see the upper portion of Fig. 11). New coastal clouds will not be produced over the bay because the supply of cold air becomes insufficient. The layered clouds that were found early in the morning become cellular, when the convective motion comes to be active because of the warm air near the sea surface and pushes up the height of the inversion. Wind shear (Brunt, 1951) between

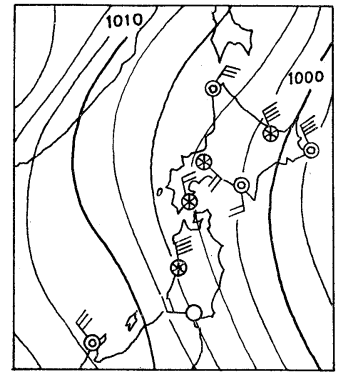

a) $03: 00$ JST 22 January 1963

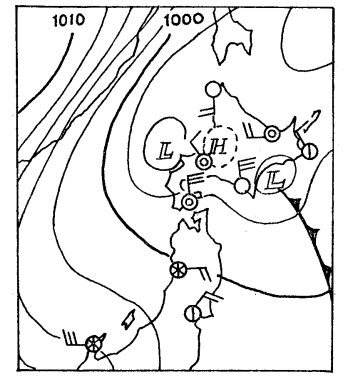

b) $03: 00$ JST 26 January 1963
Fig. 9. Surface wéather maps.

the top and the bottom layer of the clouds may contribute to arrange the cellular clouds in even lines.

\section{Concluding remarks}

The coastal clouds observed were small in horizontal scale. According to Fujita ${ }^{1}$, TIROS photographs suggested that such coastal clouds exist over Lake Michigan and Lake Superior, U.S.A., in winter. The photographs showed many lines of cellular clouds over the lakes along the expected wind direc-

1) Private communication from Dr. Fujita, the University of Chicago. 
07:00 31 JAN. 1964
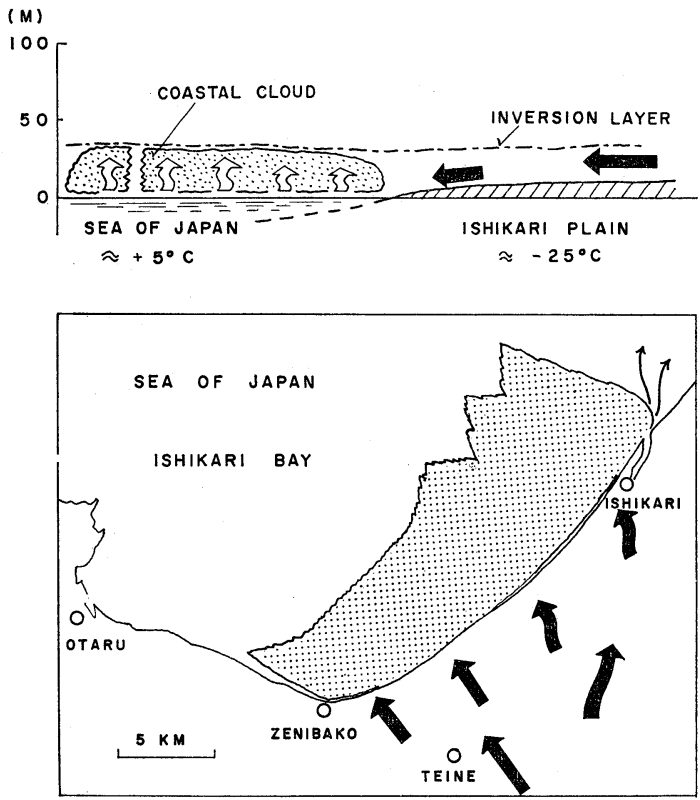

Fig. 10. Model of coastal cloud at 07:00, 31 January 1964.

tion, and some snow may be seen. The present writer considers that such coastal clouds occur when cold air flows out over a warm sea surface in winter and that they may produce snow if they occur on a large scale, even if there were no frontal ascending air nor orographic effect.

\section{Acknowledgment}

The author is the most grateful to Prof. C. Magono for his suggestions throughout the course of this work and to Messrs S. Tazawa and $T$. Endo for their cooperation in the observations, and to Dr. T. Fujita for the valuable comment based upon observation of a TIROS photograph. The author is
$09: 00 \quad 31$ JAN. 1964
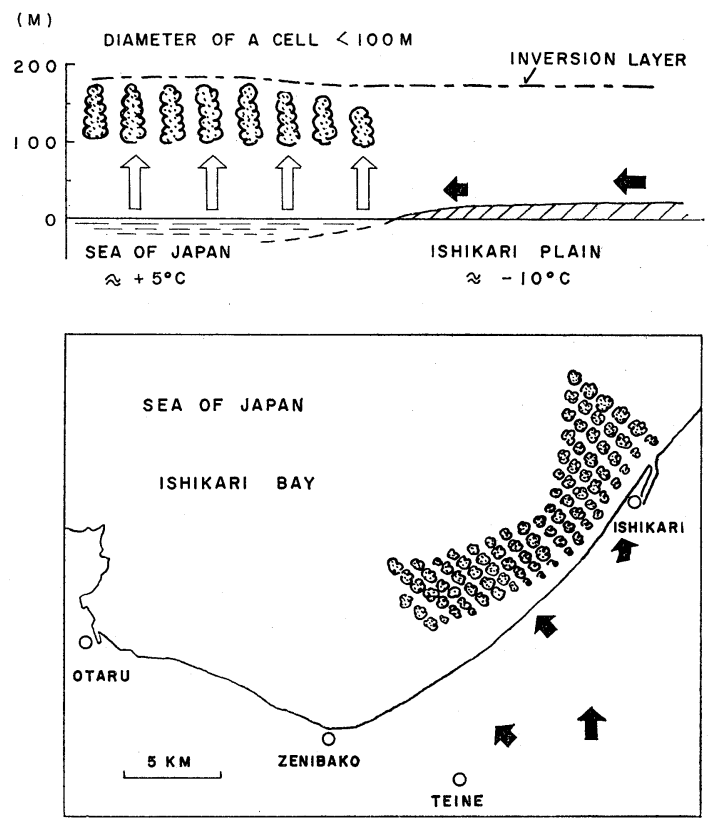

Fig. 11. Model of coastal cloud at 09:00, 31 January 1964.

much indebted to the Sapporo District Meteorological Observatory and to the local weather stations which offered data for analysis in this work.

\section{References}

Brunt, D., 1951: Experimental cloud formation. Compendium of Meteorology, Amer. Meteor. Soc., 1255-1262.

Hokkaido Regional Fisheries Research Laboratory, 1952: The reports of the sea surface temperature in Ishikari Bay. (in Japanese)

Magono, C. and K. Kikuchi, 1964: to be published. The 1st Regional Maritime Safety Headquarters, 1954: The reports of the sea surface conditions in Ishikari Bay, No. 4. (in Japanese) 


\title{
石狩湾上の “Coastal Clouds” について
}

\author{
菊 地 勝 弘
}

北海道大学理学部地球物理学教室

北海道石狩湾々上, 特飞沿岸付近飞冬期間早朝しばしば雲頂 $20 \sim 30 \mathrm{~m}$ の層状の雲が発生した。これ等の雲を手稲 山頂から 35 ミリカメラ呿よび 16 ミリムービーカメラで一定時間每飞撮影し, 観測した。その結果, はじめ層状飞発 生したこれ等の雲は日の出後時間と共汒界し, 雲頂 $200 \mathrm{~m}$ 位でセル状となり, 規則正しい列状飞配列し, 10 時前 後にいずれも消滅した。解析の結果, これ等の雲は夜間の強い輻射冷却により石狩平野上飞できた寒気が, 比較的 暖かい石狩湾上飞吹出し, 垂直混合飞より湾上の暖気が凝結してできたすのと考元られる。日の出後寒気の吹出しが 弱まり, 逆転層の上年とと屯に, これ等の雲は上䄯し, セル状となりその高度の wind shear とよって列状飞配列し たものであろろ。この論文ではこの雲を“Coastal Cloud”と名付けた。

観測された Coastal Clouds は small scale のもので降水現象を伴わなかったが，もし同様な過程で large scale 飞生ずるならば，前線や山岳効果がなくてあ降水をもたらすことが十分期待される。 